MS DANIELA NÝBLOVÁ (Orcid ID : 0000-0001-9304-6347)

Article type : Article

\title{
NMR study on reaction processes from aluminum chloride hydroxides to alpha alumina powders
}

Daniela Nýblováa, ${ }^{\mathrm{a},}$, Mamoru Senna ${ }^{\mathrm{b}}$, Andre Düvel ${ }^{\mathrm{c}}$, Paul Heitjans ${ }^{\mathrm{c}}$, Peter Billik ${ }^{\mathrm{a}, \mathrm{d}}$, Juraj Filo ${ }^{\mathrm{e}}$, Vladimír Šepelák ${ }^{\mathrm{f}}$

${ }^{a}$ Department of Inorganic Chemistry, Faculty of Natural Sciences, Comenius University in Bratislava, 84215 Bratislava, Slovakia

${ }^{\mathrm{b}}$ Faculty of Science and Technology, Keio University, 3-14-1 Hiyoshi, Japan

${ }^{c}$ Institute of Physical Chemistry and Electrochemistry, Leibniz Universität Hannover, 30167 Hannover, Germany

${ }^{\mathrm{d}}$ Department of Magnetometry, Institute of Measurement Science, Slovak Academy of Sciences, 84104 Bratislava, Slovakia

${ }^{\mathrm{e}}$ Institute of Chemistry, Faculty of Natural Sciences, Comenius University in Bratislava, 842 15 Bratislava, Slovakia

${ }^{\mathrm{f}}$ Institute of Nanotechnology, Karlsruhe Institute of Technology, 76344 EggensteinLeopoldshafen, Germany

* Corresponding author: Daniela Nýblová, daniela.nyblova@gmail.com

\section{Abstract}

Starting from gelatinous aluminum chloride hydroxide, the transformation process towards $\alpha-\mathrm{Al}_{2} \mathrm{O}_{3}$ was examined by using ${ }^{27} \mathrm{Al} \mathrm{NMR}$, both in the liquid and solid states, as a main analytical tool. By increasing the hydrolysis ratio $\left(h\right.$, defined as $\left.\left[\mathrm{OH}^{-}\right] /\left[\mathrm{Al}^{3+}\right]\right)$ of the starting aqueous precursor up to $h=2.5$, the transition temperature to the final product, $\alpha$ $\mathrm{Al}_{2} \mathrm{O}_{3}$, decreased to as low as $500{ }^{\circ} \mathrm{C}$. In this case, the structural change from amorphous alumina to $\alpha-\mathrm{Al}_{2} \mathrm{O}_{3}$ took place without intermediate transition $\mathrm{Al}_{2} \mathrm{O}_{3}$ phases.

This article has been accepted for publication and undergone full peer review but has not been through the copyediting, typesetting, pagination and proofreading process, which may lead to differences between this version and the Version of Record. Please cite this article as doi: $10.1111 /$ jace. 16108

This article is protected by copyright. All rights reserved. 
Examining the process of networking during the transition from aqueous sol — through the state of xerogel - to final anhydrous oxide by NMR revealed the presence of highly polymeric species mainly ascribed to $\delta$ - $\left[\mathrm{Al}_{2} \mathrm{O}_{8} \mathrm{Al}_{28}(\mathrm{OH})_{56}\left(\mathrm{H}_{2} \mathrm{O}\right)_{24}\right]^{18+}\left(\delta-\mathrm{Al}_{30}\right) . \delta-\mathrm{Al}_{30}$ species were found in the solution phase and became predominant after drying. We conclude that the lower temperature synthesis of $\alpha-\mathrm{Al}_{2} \mathrm{O}_{3}$ became possible due to preformation of polymerized $\mathrm{AlO}_{6}$ construction units in the precursor, reducing the energy barrier for the nucleation of the final $\alpha-\mathrm{Al}_{2} \mathrm{O}_{3}$ phase.

\section{Introduction}

$\alpha-\mathrm{Al}_{2} \mathrm{O}_{3}$ is a widely used ceramic material applied in the fields of construction, electronics, optical or biotechnology, due to its outstanding mechanical strength, chemical and electrical resistance, or thermal insulation ${ }^{1}$. Conventionally, $\alpha-\mathrm{Al}_{2} \mathrm{O}_{3}$ is fabricated by calcining aluminum hydroxides obtained from the source mineral, bauxite. It is also possible to synthesize $\alpha-\mathrm{Al}_{2} \mathrm{O}_{3}$ from various aluminum salts, e.g. chloride ${ }^{2}$, sulphate ${ }^{3}$ or nitrate ${ }^{4}$. Temperatures needed for $\alpha-\mathrm{Al}_{2} \mathrm{O}_{3}$ synthesis from aluminum hydroxides or salts are usually above $1100{ }^{\circ} \mathrm{C}^{1}$. A general transformation process includes several transition $\mathrm{Al}_{2} \mathrm{O}_{3}$ phases, which are denoted by Greek characters. Two representative transformation routes are $\chi \rightarrow \kappa$ $\rightarrow \alpha$ and $\gamma \rightarrow \delta \rightarrow \theta \rightarrow \alpha^{1,5,6}$. Transition $\mathrm{Al}_{2} \mathrm{O}_{3}$ phases differ from each other by different partition of $\mathrm{Al}$ atoms in the octahedral and tetrahedral voids of the oxygen sublattice, as well as by various defects in the sublattice. In $\alpha-\mathrm{Al}_{2} \mathrm{O}_{3}$, all $\mathrm{Al}$ atoms are localized in octahedral sites. Whereas transformations among the transition phases are displacive with low activation energies, the final stage of the transformation to the $\alpha$ modification is reconstructive, and hence requires a higher activation energy for its nucleation ${ }^{7}$. The only exception is diaspore, $\alpha-\mathrm{AlO}(\mathrm{OH})$, which directly transforms to $\alpha-\mathrm{Al}_{2} \mathrm{O}_{3}$ at relatively low temperatures, since its structure is similar to that of $\alpha-\mathrm{Al}_{2} \mathrm{O}_{3}{ }^{1}$. However, diaspore occurs in nature to a very low 
extent and its synthesis is laborious requiring hydrothermal conditions with high temperature and pressure ${ }^{8}$. Therefore, diaspore is not suitable as a starting material of $\alpha-\mathrm{Al}_{2} \mathrm{O}_{3}$ on a production scale.

The aim of this work is to examine the reaction processes from non-conventional starting materials in a liquid phase and to find a transition temperature as low as possible to the final product, $\alpha-\mathrm{Al}_{2} \mathrm{O}_{3}$. A decrease in the synthesis temperature is favorable not only from economic and environmental aspects, but also with regard to smaller crystallite or particle sizes in a highly dispersed state.

Some attempts of decreasing the synthesis temperature of $\alpha-\mathrm{Al}_{2} \mathrm{O}_{3}$ have already been reported. The lowest $\alpha-\mathrm{Al}_{2} \mathrm{O}_{3}$ synthesis temperature of $420{ }^{\circ} \mathrm{C}$ was reported by Brand et al. ${ }^{2}$. In some other works $\alpha-\mathrm{Al}_{2} \mathrm{O}_{3}$ was synthesized at around $500{ }^{\circ} \mathrm{C}^{8-11}$. The precursors in the reported cases could be categorized as gelatinous aluminum hydroxides, however, this designation is indefinite without elucidating features specific to the starting materials.

Here we focus on the low-temperature synthesis of $\alpha-\mathrm{Al}_{2} \mathrm{O}_{3}$ from gelatinous aluminum chloride hydroxide $(\mathrm{ACH})$. We examine $\mathrm{ACH}$ xerogels with different hydrolysis ratio $h\left(=\left[\mathrm{OH}^{-}\right] /\left[\mathrm{Al}^{3+}\right]\right)$ prepared by sol-gel partial hydrolysis. Apart from conventional analyses by thermal analysis and powder X-ray diffraction analysis, we focus on ${ }^{27} \mathrm{Al}$ nuclear magnetic resonance (NMR) spectroscopy both in the liquid and solid phases. This enables us to reveal the states and their variation in short-range ordering in terms of networking and polymerization of Al-containing clusters throughout the entire processes from the starting solution to the final $\alpha-\mathrm{Al}_{2} \mathrm{O}_{3}$ powders.

This article is protected by copyright. All rights reserved. 


\section{Experimental Procedure}

\subsection{Preparation}

Whereas ACHs are mostly synthesized by neutralization of $\mathrm{Al}^{3+}$ solution by basic solution, the $\mathrm{ACH}$ gels in this work were prepared by dissolving $\mathrm{Al}$ metal in aqueous $\mathrm{AlCl}_{3}$ solution so that most of the conditions remain the same with different hydrolysis ratio, $h=\left[\mathrm{OH}^{-}\right] /\left[\mathrm{Al}^{3+}\right]$ (i.e. the same molar concentration of $\mathrm{Al}$ in solution assured by constant solution volume, absence of other cations beside $\mathrm{Al}$ ). Gelatinous $\mathrm{ACH}$ samples with different hydrolysis ratio were synthesized by dissolving chopped $\mathrm{Al}$ wire $(99.5 \%, 3 \mathrm{~mm}$ in diameter, Kadaň, Slovakia) in $\mathrm{AlCl}_{3}$ solution with fixed volume of $50 \mathrm{ml}$ prepared from $\mathrm{AlCl}_{3} \cdot 6 \mathrm{H}_{2} \mathrm{O}$ (98\%, Lachema Brno, Czech Republic) and deionized water. The amounts of Al metal and $\mathrm{AlCl}_{3} \cdot 6 \mathrm{H}_{2} \mathrm{O}$ were varied while keeping the molar concentration of $\left[\mathrm{Al}^{3+}\right]$ constant at 1.85 M. The temperature of synthesis was $95{ }^{\circ} \mathrm{C}$ and the range of tested $h$ was $0-2.5$. We henceforth denote our ACH samples with $h$ values as ACH- $h$. At values of $h$ exceeding 2.5, crystalline aluminum hydroxides or oxyhydroxides start to precipitate. These precipitates lead to the known transformation sequence to $\alpha-\mathrm{Al}_{2} \mathrm{O}_{3}$ requiring temperature treatment above $1100{ }^{\circ} \mathrm{C}^{1}$. As-synthesized viscous liquids (ACH solutions) were dried at $95{ }^{\circ} \mathrm{C}$ for $2-3$ days to obtain a series of $\mathrm{ACH}$ xerogels. The samples prepared at varying hydrolysis ratio are summarized in Table 1 . The ACH xerogels were heated in a laboratory furnace CLASIC CZ $1013 \mathrm{~L}$ in static air atmosphere with a heating rate of $10{ }^{\circ} \mathrm{C} / \mathrm{min}$ and held for $2 \mathrm{~h}$ at the selected plateau temperatures. A scheme of the experimental procedure is shown in Figure 1.

\subsection{Characterization}

Powder X-ray diffraction analyses (XRD) were carried out with a Philips PW 1050 diffractometer with Bragg-Brentano geometry and $\mathrm{CuK}_{\alpha}$ radiation. 
TG-DTA measurements were performed by using a TA Instruments SDT 2960 up to $1200{ }^{\circ} \mathrm{C}$ with a heating rate of $10^{\circ} \mathrm{C} / \mathrm{min}$ in air flow.

Liquid state ${ }^{27} \mathrm{Al}$ NMR measurements of as-prepared ACH solutions were carried out with a Varian Mercury Plus $300 \mathrm{MHz}$ spectrometer with a Varian 1H/19F/X 5 mm PFG ATB probe. ${ }^{27} \mathrm{Al}$ has a Larmor frequency $\left(v_{0}\right)$ of $78.2 \mathrm{MHz}$ at this magnetic field strength. The length of an excitation pulse for ${ }^{27} \mathrm{Al}$ was $5.8 \mu \mathrm{s}$ at $53 \mathrm{~dB} .1024$ scans were accumulated for each spectrum.

For solid-state ${ }^{27} \mathrm{Al}$ MAS-NMR measurements, two spectrometers were used, and the spectra were recorded in a single pulse sequence. As-synthesized ACH xerogels were studied using a Bruker Avance III $600 \mathrm{MHz}$ NMR spectrometer providing a magnetic field of $14.1 \mathrm{~T}$, which corresponds to a ${ }^{27} \mathrm{Al}$ NMR Larmor frequency of $156.4 \mathrm{MHz}$. A $1.3 \mathrm{~mm}$ MAS probe (Bruker, Germany) was used with $40 \mathrm{kHz}$ spinning rate $\left(v_{\text {rot }}\right)$. The $\pi / 2$-pulse length was $1.0 \mu \mathrm{s}$, and the recycle delay of $10 \mathrm{~s}$ ensured full spin-lattice relaxation. 256 scans were accumulated for each spectrum. The heat-treated ACH samples were studied with a Bruker Avance III $300 \mathrm{MHz}$ NMR spectrometer with a magnetic field of $7.0 \mathrm{~T}$, which corresponds to a ${ }^{27}$ Al NMR Larmor frequency of 78.2 MHz. A 4 mm MAS probe (Bruker, Germany) and a spinning rate of $15 \mathrm{kHz}$ were chosen. The $\pi / 2$-pulse length was $2.0 \mu$ s and the recycle delay of $10 \mathrm{~s}$ ensured full spin-lattice relaxation. At least 1024 scans were accumulated for each spectrum.

All NMR measurements were performed at room temperature and all NMR spectra were referenced to an aqueous $\mathrm{Al}\left(\mathrm{NO}_{3}\right)_{3}$ solution. Characterization techniques are also summarized in Fig. 1 with the number of the associated figure to be displayed below.

This article is protected by copyright. All rights reserved. 


\section{$3 \quad$ Results and Discussion}

\subsection{Characterization of the Precursors}

\subsubsection{Solution ${ }^{27}$ Al NMR}

The course of hydrolysis of $\mathrm{Al}^{3+}$ in our $\mathrm{ACH}$ solutions with increasing $h$ is consistent with literature data ${ }^{12,13}$. In diluted acidic aqueous $\mathrm{Al}^{3+}$ solutions, the dominant form of aluminum is a hydrated cation, $\left[\mathrm{Al}\left(\mathrm{H}_{2} \mathrm{O}\right)_{6}\right]^{3+}$. Polarization of $\mathrm{H}_{2} \mathrm{O}$ molecules by $\mathrm{Al}^{3+}$ leads to deprotonation of hydrated cations according to Eq. 1. These deprotonated hydrated cations then may form dimers (Eq. 2) and higher polymeric species according to conditions such as temperature, $\mathrm{pH}$ and presence of different anionic species.

$$
\begin{aligned}
& {\left[\mathrm{Al}\left(\mathrm{H}_{2} \mathrm{O}\right)_{6}\right]^{3+} \rightarrow\left[\mathrm{Al}(\mathrm{OH})\left(\mathrm{H}_{2} \mathrm{O}\right)_{5}\right]^{2+}+\mathrm{H}^{+}} \\
& 2\left[\mathrm{Al}(\mathrm{OH})\left(\mathrm{H}_{2} \mathrm{O}\right)_{5}\right]^{2+} \rightarrow\left[\mathrm{Al}_{2}(\mathrm{OH})_{2}\left(\mathrm{H}_{2} \mathrm{O}\right)_{8}\right]^{3+}+2 \mathrm{H}_{2} \mathrm{O}
\end{aligned}
$$

Higher amounts of $\mathrm{OH}^{-}$in a solution, i.e. higher $h$ values, promote condensation reactions by neutralization, leading to a higher degree of polymerization ${ }^{13}$. This trend is universal no matter the aluminum salt used as starting material ${ }^{14}$.

Nevertheless a large number of polymeric $\mathrm{Al}$ species in $\mathrm{Al}^{3+}$ solutions have been theoretically proposed ${ }^{1}$, yet, only a few of them have been characterized (vide infra). Alcontaining polymeric species are divided into two categories according to their morphology. The first group of these species is formed by connecting trimers of $\mathrm{AlO}_{6}$ into "flat" structures. Its representative is the tridecamer $\mathrm{Al}_{13}(\mathrm{OH})_{24}\left(\mathrm{H}_{2} \mathrm{O}\right)_{24}{ }^{15+}\left(\mathrm{M}-\mathrm{Al}_{13}\right)$ with so-called "Mögel" structure, which consists merely of interconnected $\mathrm{AlO}_{6}$ octahedra ${ }^{15}$. The second group differs from the first one by the presence of Keggin moiety, which consists of $\mathrm{AlO}_{4}$ tetrahedra surrounded by $\mathrm{AlO}_{6}$ units forming a more spacious structure. Several polymeric $\mathrm{Al}$ species possessing different isomers of Keggin ions (denoted by Greek character prefix) have been 
characterized, e. g. $\varepsilon-\mathrm{AlO}_{4} \mathrm{Al}_{12}(\mathrm{OH})_{24}\left(\mathrm{H}_{2} \mathrm{O}\right)_{12}{ }^{7+}\left(\varepsilon-\mathrm{K}_{-}-\mathrm{Al}_{13}\right){ }^{16}$ and $\delta$ $\left[\mathrm{Al}_{2} \mathrm{O}_{8} \mathrm{Al}_{28}(\mathrm{OH})_{56}\left(\mathrm{H}_{2} \mathrm{O}\right)_{24}\right]^{18+}\left(\delta-\mathrm{Al}_{30}\right){ }^{17}$.

In our ACH solutions with low $h$, only monomers and small oligomers, mainly dimers and trimers, are observed according to ${ }^{27} \mathrm{Al}$ NMR (Fig. 2). All samples with a hydrolysis ratio up to 2.0 exhibit main resonance peaks with a chemical shift at around $0 \mathrm{ppm}$. The peak was assigned either to hydrated $\mathrm{Al}$ monomers $\left(\left[\mathrm{Al}\left(\mathrm{H}_{2} \mathrm{O}\right)_{6}\right]^{3+},\left[\mathrm{Al}(\mathrm{OH})\left(\mathrm{H}_{2} \mathrm{O}\right)_{5}\right]^{2+}\right.$, $\left[\mathrm{Al}(\mathrm{OH})_{2}\left(\mathrm{H}_{2} \mathrm{O}\right)_{4}\right]^{+13,18}$ ) or to peripheral $\mathrm{AlO}_{6}$ in $\mathrm{M}^{-\mathrm{Al}_{13}}{ }^{19}$. The other signal assigned to $\mathrm{M}$ $\mathrm{Al}_{13}$ has a chemical shift in the range of $2-15 \mathrm{ppm}^{19}$. Therefore, ACH- 0.0 consists only of hydrated $\mathrm{Al}$ monomers. For ACH-0.5, the resonance peak at 0 ppm remained predominant. However, small peaks at around 4 ppm were observed, as shown in the magnified inset. They might be ascribed to dimers or trimers of $\mathrm{Al}^{20}$, and/or $\mathrm{M}-\mathrm{Al}_{13}{ }^{19}$. Exact assignment of the latter small peak is not possible since the signals reported for these species are in the same region and are also broadened due to the surrounding electric field gradients ${ }^{19-22}$. The intensity of the $0 \mathrm{ppm}$ signal diminishes with increasing hydrolysis ratio due to the polymerization of $\mathrm{Al}$ monomers ${ }^{13}$. The signal of $\mathrm{Al}$ dimers/trimers at around $2-5 \mathrm{ppm}$ is present in the range of $0.5 \leq h \leq 2.0$. The distinct peak at $62.9 \mathrm{ppm}$ was assigned to $\mathrm{AlO}_{4}$ in a highly symmetrical environment of $\varepsilon-\mathrm{K}-\mathrm{Al}_{13}{ }^{21,22} \cdot \varepsilon-\mathrm{K}-\mathrm{Al}_{13}$ is present in the $\mathrm{ACH}$ samples possessing $1.2 \leq h \leq 2.5$. The samples with hydrolysis ratio 2.0 and 2.5 exhibit a signal at $10-$ $12 \mathrm{ppm}$, which, theoretically, may originate from the $\mathrm{AlO}_{6}$ moieties present in either $\delta$ - $\mathrm{Al}_{30}$ or $\varepsilon-\mathrm{K}_{-}-\mathrm{Al}_{13}{ }^{17}$. In contrast to $\delta-\mathrm{Al}_{30}$, the NMR signal in this region originating from $\mathrm{AlO}_{6}$ is not observable for $\varepsilon-\mathrm{K}-\mathrm{Al}_{13}$ at ambient temperature due to large electric field gradients ${ }^{19}$. A very broad signal at ca. $71 \mathrm{ppm}$ present in the spectrum of $\mathrm{ACH}-2.5$ also points to the presence of $\delta-\mathrm{Al}_{30}{ }^{18,23}$.

This article is protected by copyright. All rights reserved. 


\subsubsection{Solid-State ${ }^{27}$ Al MAS-NMR}

Solid-state ${ }^{27} \mathrm{Al}$ MAS-NMR spectra of as-synthesized ACH xerogels are shown in Fig. 3. The spectrum of the ACH- 0.0 (Fig. 3a) contains only one narrow signal at $-1.0 \mathrm{ppm}$. This indicates that all the $\mathrm{Al}$ atoms are situated in a very symmetrical octahedral environment of oxygen atoms. The spectrum of the ACH-0.5 (Fig. 3b) shows also a narrow signal at $-0.9 \mathrm{ppm}$ which is one-side broadened downfield up to ca. $15 \mathrm{ppm}$ suggesting some degree of disorder of octahedral Al sites ${ }^{24,25}$.

In the NMR spectra of the samples with $h>0.5$, all signals are markedly broadened. The broadening and asymmetry of the line shapes of $\mathrm{AlO}_{4}$, and to lower extent also of $\mathrm{AlO}_{6}$, stems from the second-order quadrupolar broadening in solid samples ${ }^{24,25}$. ACH-1.2 (Fig. 3c) contains 3 broad signals with maxima at 5.1, 35.6 and $64.3 \mathrm{ppm}$. They correspond to Al atoms coordinated by 6,5 and 4 oxygen atoms, respectively ${ }^{26}$. The signal at $64.3 \mathrm{ppm}$ is very close to the signal at $64.5 \mathrm{ppm}$ firstly assigned to the derivate of $\mathrm{K}-\mathrm{Al}_{13}$ distorted by lack ${ }^{18}$ or excess ${ }^{27}$ of one $\mathrm{AlO}_{6}$ unit. More recently, it was assumed to be the $\delta$-isomer of $\mathrm{Al}_{13}$ with Keggin structure $\left(\delta-\mathrm{K}-\mathrm{Al}_{13}\right)^{28}$. ACH-2.0 (Fig. 3d) possesses also all three types of coordination of $\mathrm{Al}$. The $75.1 \mathrm{ppm}$ signal corresponding to 4-coordinated $\mathrm{Al}$ is downfield shifted and narrower than the $\mathrm{AlO}_{4}$ signal found in $\mathrm{ACH}-1.2$. The peak at $75.1 \mathrm{ppm}$ was assigned to $\mathrm{AlO}_{4}$ in the $\gamma$-isomer of $\mathrm{Al}$ tridecamer with Keggin structure $\left(\gamma-\mathrm{K}-\mathrm{Al}_{13}\right)^{29,30}$. The signal of 5-coordinated $\mathrm{Al}(34.6 \mathrm{ppm})$ has the same peak position as in the $\mathrm{ACH}-1.2$ sample, but its intensity is lower, suggesting a lower amount of 5-coordinated Al present in the ACH2.0 sample. The lower amount of $\mathrm{AlO}_{5}$ may be caused by a higher amount of $\mathrm{Al}$ atoms that form specific polymers containing only $\mathrm{AlO}_{4}$ and $\mathrm{AlO}_{6}$ at higher $h$. At lower $h$, the species seem to contain more $\mathrm{Al}$ atoms in a transient $\mathrm{AlO}_{5}$ state. The NMR lines of highest intensity in the spectrum of $\mathrm{ACH}-2.0$ (Fig. 3d) are attributed to 6-coordinated $\mathrm{Al}$ atoms. Two distinct components at 3.9 and $10.1 \mathrm{ppm}$ are clearly visible in the spectrum. The NMR spectrum of 
the ACH-2.5 sample (Fig. 3e) reveals the presence of 6- and 4-coordinated Al, with 5coordinated $\mathrm{Al}$ being absent. It contains 6-coordinated $\mathrm{Al}$ signals (10.2 ppm, $4.5 \mathrm{ppm})$ similar to that of ACH-2.0. The most intense one is the component at $10.2 \mathrm{ppm}$. Besides the NMR lines of 6-coordinated $\mathrm{Al}$, the $\mathrm{ACH}-2.5$ spectrum contains a signal at $-27.6 \mathrm{ppm}$, and two signals at 74.5 and $67.5 \mathrm{ppm}$, being typical for $\mathrm{AlO}_{4}$. Very similar looking spectra to that of ACH-2.5 were assigned by Phillips et al. ${ }^{31}$ to $\delta$ - $\mathrm{Al}_{30}$ polycations. They assigned the broad NMR lines at around $-50 \mathrm{ppm}$ in their spectra to edge-linked $\mathrm{AlO}_{6}$ trimers surrounding a tetrahedrally coordinated $\mathrm{Al}$ atom in the $\varepsilon$-Keggin-like structures. In the ${ }^{27} \mathrm{Al}$ MAS-NMR spectrum of $\mathrm{ACH}-2.5$, the feature near $-27.6 \mathrm{ppm}$ corresponds to the same moieties with respect to the different magnetic field strength compared to that used in the work of Phillips et al. ${ }^{31}$. However, the presence of other than $\delta-\mathrm{Al}_{30}$ species in $\mathrm{ACH}-2.5$ to a minor extent may not be excluded.

\subsubsection{Changes in the Short-Range Order from Sol to Xerogel}

Herein, the rearrangement of $\mathrm{Al}$ species during the drying process is discussed by comparing solid and liquid state ${ }^{27} \mathrm{Al}$ NMR spectra. In general, there are well-known differences between liquid and solid-state NMR spectra mainly due to the lack of averaging of the dipolar interactions, the chemical shift anisotropy and the second-order quadrupole interaction in the latter. Under the MAS-NMR measuring conditions used in this study the dipolar interactions and the chemical shift anisotropy are effectively averaged; however, the second-order quadrupole interaction persists. This becomes critical when we consider the rearrangement within the transformation from liquid to solid phase.

Drying at $95{ }^{\circ} \mathrm{C}$ promotes the aging process of the solutions, leading to the formation of high polymeric $\mathrm{Al}$ species from monomeric and low-order polymeric hydrated Al

This article is protected by copyright. All rights reserved. 
species $^{21,22,27}$. The transformations of the $\mathrm{Al}$ species during aging were extensively discussed from the viewpoints of hydrated $\mathrm{Al}$ polyoxocation in the literature ${ }^{32}$.

In the case of the samples containing mostly monomers (ACH-0.0, $\mathrm{ACH}-0.5)$, the correlation between solid (Fig. 3) and liquid state (Fig. 2) NMR spectra is obvious. The samples contain only octahedral signals ascribed to Al monomers both in liquid and solid states. Polymerization to higher polymers was not observed after drying. However, in the spectra of the samples with higher hydrolysis ratio, some discrepancies occur, as a consequence of structural change during the aging process. In addition to signals for $\mathrm{AlO}_{6}$ and $\mathrm{AlO}_{4}$ in the liquid spectrum of $\mathrm{ACH}-1.2$, a signal of 5-coordinated $\mathrm{Al}$ appeared in the spectrum of the solid. Employing molecular dynamics simulations, Rustad et al. ${ }^{33}$ suggested the presence of metastable 5 -fold coordinated $\mathrm{Al}$ in $\varepsilon-\mathrm{K}-\mathrm{Al}_{13}$. As the origin thereof, breaking of the bond between $\mathrm{Al}$ in octahedral coordination and $\mu_{4}-\mathrm{O}$ linked to central tetrahedrally coordinated $\mathrm{Al}$ was put forward - which is the initial step in oxygen exchange process for the bridging hydroxyl groups ${ }^{33}$. Similar mechanism may occur in the case of ACH-1.2 during drying leading to cluster condensation, which requires replacement of terminal $\mathrm{H}_{2} \mathrm{O}$ groups by $\mathrm{OH}$ groups ${ }^{33}$. The broad, weak signal in the ${ }^{27} \mathrm{Al}$ MAS-NMR spectrum of ACH-1.2 at $64.3 \mathrm{ppm}$ may be ascribed to the $\delta$-Keggin-structure formed by modification of $\varepsilon-\mathrm{K}-\mathrm{Al}_{13}{ }^{27}$ present in the liquid sample. The largest discrepancy between the liquid sample and the xerogel was observed for $\mathrm{ACH}-2.0$. The signal for $\varepsilon-\mathrm{K}-\mathrm{Al}_{13}$ disappears completely and a signal at ca. 75 ppm appears, suggesting that the $\varepsilon-\mathrm{K}-\mathrm{Al}_{13}$ transformed, at least partly, to $\gamma-\mathrm{K}$ $\mathrm{Al}_{13}$ during drying. This is also confirmed by the simultaneous occurrence of an NMR line at 10 ppm matching the 7-11 ppm region, assigned to the $\mathrm{AlO}_{6}$ in $\gamma-\mathrm{K}-\mathrm{Al}_{13}{ }^{29}$. However, we cannot exclude the formation of other polymeric $\mathrm{Al}$ species, which cannot be tracked by ${ }^{27} \mathrm{Al}$ NMR. As observed for ACH-1.2, also in the ACH-2.0 a signal caused by 5-coordinated Al occurs, but with lower intensity compared to the ACH-1.2 sample. For the ACH-2.5 sample, 
both liquid and solid-state NMR spectra suggest the presence of $\delta-\mathrm{Al}_{30}$. However, in the liquid NMR spectrum, also $\varepsilon-\mathrm{K}-\mathrm{Al}_{13}$ was present, which is absent in the solid-state NMR spectrum. This ambiguity may be explained by assuming that $\varepsilon-\mathrm{K}-\mathrm{Al}_{13}$ polymerized to $\delta-\mathrm{Al}_{30}$ during drying the liquid sample to xerogel, which could occur upon heating ${ }^{34}$. The presence of the feature near $-30 \mathrm{ppm}$ in MAS-NMR spectrum of ACH-2.5 indicates retention of the liable terminal $\mathrm{H}_{2} \mathrm{O}$ groups after drying, which enhance further reactivity (vide infra) ${ }^{31}$ The summarized results from solution and solid-state NMR are shown in Tab. 1

\subsection{Heat-Treatments of the ACH Xerogels}

\subsubsection{Thermal Analysis}

Thermal analyses of the ACH xerogels are shown in Fig. 4. After dehydration of adsorbed $\mathrm{H}_{2} \mathrm{O}$ at temperatures up to $100{ }^{\circ} \mathrm{C}, \mathrm{ACH}-0.0$ decomposes in a single step exhibiting an endothermic effect with peak minimum at $191^{\circ} \mathrm{C}$ to amorphous $\mathrm{Al}_{2} \mathrm{O}_{3}$, which contains some amount of remaining - $\mathrm{OH}$ groups. The phase transformation of amorphous $\mathrm{Al}_{2} \mathrm{O}_{3}$ to $\gamma$ $\mathrm{Al}_{2} \mathrm{O}_{3}$ is accompanied by an exothermic peak with a maximum at $846^{\circ} \mathrm{C}$ and the transformation of $\gamma-\mathrm{Al}_{2} \mathrm{O}_{3}$ to $\alpha-\mathrm{Al}_{2} \mathrm{O}_{3}$ by a broad exothermic peak with a maximum at $1135^{\circ} \mathrm{C}$. At about $800{ }^{\circ} \mathrm{C}$, further weight loss occurs due to dehydroxylation. In all samples the largest weight losses occur up to $300{ }^{\circ} \mathrm{C}$. With rising value of $h$, the weight losses are divided into several steps, revealing the samples consist of several differently bound $-\mathrm{OH}$ groups. This is also reflected by DTA curves, in which the corresponding endothermic peaks broaden, comprising several overlapping components up to $400{ }^{\circ} \mathrm{C}$. For $\mathrm{ACH}-0.5$, the exothermic peaks at $827^{\circ} \mathrm{C}$ and $1119^{\circ} \mathrm{C}$ corresponding to the transformation to $\gamma-\mathrm{Al}_{2} \mathrm{O}_{3}$ and $\alpha-\mathrm{Al}_{2} \mathrm{O}_{3}$, respectively, occur at slightly lower temperatures comparing to $\mathrm{ACH}-0.0$. The exothermic effects for $\mathrm{ACH}-1.2$ caused by the transformations to $\gamma-\mathrm{Al}_{2} \mathrm{O}_{3}\left(834{ }^{\circ} \mathrm{C}\right)$ and $\alpha$ $\mathrm{Al}_{2} \mathrm{O}_{3}\left(1118^{\circ} \mathrm{C}\right)$ are similar to previously mentioned samples. However, $\mathrm{ACH}-1.2$ contains 
an additional exothermic peak at $678{ }^{\circ} \mathrm{C}$ due to the direct low-temperature transformation of a part of the sample to $\alpha-\mathrm{Al}_{2} \mathrm{O}_{3}$. A similar exothermic peak occurs in $\mathrm{ACH}-2.0$ at $687^{\circ} \mathrm{C}$. For the two samples with the highest $h$, the exothermic peak ascribed to the transformation of $\gamma$ $\mathrm{Al}_{2} \mathrm{O}_{3}$ to $\alpha-\mathrm{Al}_{2} \mathrm{O}_{3}$ diminishes, with no recognizable peak in $\mathrm{ACH}-2.5$. The fluctuations of the DTA curves above $600{ }^{\circ} \mathrm{C}$ are caused by simultaneous transformations of multiple phase systems to final $\alpha-\mathrm{Al}_{2} \mathrm{O}_{3}$.

\subsubsection{Powder X-Ray Diffraction}

The phase compositions of heat-treated ACH xerogels tracked by XRD are shown in Fig.

5. All heat-treated samples were amorphous up to a temperature of $400{ }^{\circ} \mathrm{C}$ according to XRD and thus their XRD patterns are omitted in the figure. The lowest temperatures of $\alpha-\mathrm{Al}_{2} \mathrm{O}_{3}$ formation from the five different $\mathrm{ACH}$ xerogels after $2 \mathrm{~h}$ heat-treatments are summarized in Tab. 1. The lowest temperature was $500{ }^{\circ} \mathrm{C}$ starting from $\mathrm{ACH}-2.5$. Since no transition $\mathrm{Al}_{2} \mathrm{O}_{3}$ was observed by XRD up to heat-treatment at $500{ }^{\circ} \mathrm{C}$, it can be assumed $\alpha-\mathrm{Al}_{2} \mathrm{O}_{3}$ formed from amorphous $\mathrm{Al}_{2} \mathrm{O}_{3}$ following an unusual transformation sequence without passing through transition $\mathrm{Al}_{2} \mathrm{O}_{3}$ polymorphs. The low-temperature transformation to $\alpha-\mathrm{Al}_{2} \mathrm{O}_{3}$ may take place due to the structures of the $\mathrm{Al}$ polycations present in xerogels with higher $h$. Contrary to the case of diaspore, these $\mathrm{Al}$ polycations do not possess a hexagonal close packed arrangement of an oxygen sublattice similar to $\alpha-\mathrm{Al}_{2} \mathrm{O}_{3}$; however, their approximately cubic close packed oxygen sublattice may be more easily rearranged to hexagonal close packed one due to low energy barrier presumably originating from the terminal $\mathrm{H}_{2} \mathrm{O}$ group sites $^{33}$. The starting temperature of $\alpha-\mathrm{Al}_{2} \mathrm{O}_{3}$ synthesis for $\mathrm{ACH}-1.2$ and $\mathrm{ACH}-2.0$ was $600{ }^{\circ} \mathrm{C}$. The intensity of the diffraction series of $\alpha-\mathrm{Al}_{2} \mathrm{O}_{3}$ is quite low and increases with increasing $h$. The intensities of the $\alpha-\mathrm{Al}_{2} \mathrm{O}_{3}$ diffractions after heat-treatment at $600{ }^{\circ} \mathrm{C}$ are recognizably higher for $\mathrm{ACH}-2.5$ than for the other samples.

This article is protected by copyright. All rights reserved. 
After the heat-treatment at $600{ }^{\circ} \mathrm{C}$, broad diffractions assigned to $\gamma-\mathrm{Al}_{2} \mathrm{O}_{3}$-all broad unassigned diffractions in Fig. 5- appeared in all the samples except ACH-0.0 and ACH0.5. $\gamma-\mathrm{Al}_{2} \mathrm{O}_{3}$ formed from the residual material of the samples that had not yet been transformed to $\alpha-\mathrm{Al}_{2} \mathrm{O}_{3}$ at low T. An increase of the diffraction intensities of both $\alpha-\mathrm{Al}_{2} \mathrm{O}_{3}$ and $\gamma-\mathrm{Al}_{2} \mathrm{O}_{3}$ occurs with rising temperatures up to $1000{ }^{\circ} \mathrm{C}$. After heating at $800{ }^{\circ} \mathrm{C}$ and $1000{ }^{\circ} \mathrm{C}$, the $\mathrm{ACH}-0.5$ exhibits $\gamma-\mathrm{Al}_{2} \mathrm{O}_{3}$ as well, which transforms to $\alpha-\mathrm{Al}_{2} \mathrm{O}_{3}$ at higher temperatures. All samples contain only $\alpha-\mathrm{Al}_{2} \mathrm{O}_{3}$ after heating at $1200{ }^{\circ} \mathrm{C}$ for $2 \mathrm{~h}$. These results from XRD are in line with those from DTA-TG. Slightly higher transformation temperatures observed by DTA compared to XRD are caused by kinetic factors, since the heating regimes during thermal analyses and heat-treatments in laboratory furnace were not the same.

It should be noted that Brand et al. proposed, that the removal of reaction gases particularly $\mathrm{HCl}$ and $\mathrm{H}_{2} \mathrm{O}$ - released within the transformations during the heat-treatments of aluminum chloride hydroxide gel ${ }^{2}$ is necessary to obtain $\alpha-\mathrm{Al}_{2} \mathrm{O}_{3}$ at a temperature of around $500{ }^{\circ} \mathrm{C}$. In our case, $\alpha-\mathrm{Al}_{2} \mathrm{O}_{3}$ is formed from $\mathrm{ACH}-2.5$ at $500{ }^{\circ} \mathrm{C}$ even in static air atmosphere, without removing the gases by air stream compared to work of Brand et al. ${ }^{2}$. However, we cannot conclude whether or not the removal of the reaction gases is crucial, since we do not have any further information about gases' partial pressures in the systems to compare.

\subsubsection{Solid-State ${ }^{27}$ Al MAS-NMR}

The transformations of the $\mathrm{ACH}$ samples after heat-treatments were tracked also by ${ }^{27} \mathrm{Al}$ MAS-NMR as shown in Fig. 6. After the heat-treatments at lower temperatures $\left(200{ }^{\circ} \mathrm{C}\right.$ and $400{ }^{\circ} \mathrm{C}$ ) the signal of 5 -coordinated $\mathrm{Al}$ occurred in all samples together with diminishing intensities of $\mathrm{AlO}_{6}$ and increasing intensities of $\mathrm{AlO}_{4}$. The latter is apparent after heat- 
treatment at $400{ }^{\circ} \mathrm{C}$. The NMR spectra reveal that the formation of amorphous alumina during dehydration/dehydroxylation of $\mathrm{ACHs}$ proceeds by eliminating oxygen atoms from the 6-coordination sphere of $\mathrm{Al}$ atoms to form transient $\mathrm{AlO}_{5}$ and $\mathrm{AlO}_{4}$ besides $\mathrm{AlO}_{6}{ }^{33,35}$. Crystallization of $\mathrm{Al}_{2} \mathrm{O}_{3}$ further requires rearrangement of oxygen atoms and elimination of $\mathrm{AlO}_{5}$ units. This correlates with the phase transformations observed by the XRD measurements (Fig. 5). Vanishing of the $\mathrm{AlO}_{5}$ signal at the lowest temperature is evident for ACH-2.5 (Fig. 6e). After the heat-treatment at $500{ }^{\circ} \mathrm{C}$, its NMR spectrum contains predominantly $\mathrm{AlO}_{6}$ with a bit of $\mathrm{AlO}_{4}$ units, indicating the coexistence of a small amount of $\gamma$ - or amorphous $\mathrm{Al}_{2} \mathrm{O}_{3}$ besides $\alpha-\mathrm{Al}_{2} \mathrm{O}_{3}$. After heating at $1200{ }^{\circ} \mathrm{C}$, all samples contain solely $\alpha-\mathrm{Al}_{2} \mathrm{O}_{3}$ with only one NMR signal from 6-fold coordinated $\mathrm{Al}$ at 9.5-9.8 ppm.

The lowest $\alpha-\mathrm{Al}_{2} \mathrm{O}_{3}$ synthesis temperature of $420{ }^{\circ} \mathrm{C}$ was reported by Brand et. al. ${ }^{2}$, by using aluminum chloride hydroxide gel prepared from partially thermally decomposed $\mathrm{AlCl}_{3} \cdot 6 \mathrm{H}_{2} \mathrm{O}$. The composition of the starting gel was, however, not determined. It was assumed from IR that its structure is similar to diaspore, and from ${ }^{27} \mathrm{Al}$ MAS-NMR that it contains 6- and 4-coordinated $\mathrm{Al}(9.1,58.6 \mathrm{ppm})^{36}$. During the heat-treatment, the amount of 5-coordinated $\mathrm{Al}$ increased and subsequently diminished to form $\alpha-\mathrm{Al}_{2} \mathrm{O}_{3}$ with the signals at 12.9 and $62.7 \mathrm{ppm}^{37}$. It should be noted, that pure $\alpha-\mathrm{Al}_{2} \mathrm{O}_{3}$ should produce a single octahedral signal in NMR, so the latter signal in tetrahedral region originates most probably from some structural defects or not-yet converted transition $\mathrm{Al}_{2} \mathrm{O}_{3}$. Despite our finding, that the transformations of $\mathrm{ACH}$ xerogels to $\alpha-\mathrm{Al}_{2} \mathrm{O}_{3}$ proceeding via 5-coordinated $\mathrm{Al}$ state, is consistent with that for the sample referred in the work of Brand et al. ${ }^{2}$, the ${ }^{27}$ Al MAS-NMR signals of the ACH-2.5 xerogel differ slightly from those of the aluminum chloride hydroxide gel referred in ${ }^{2}$. Despite such a subtle difference, it is likely, that the sample referred in ${ }^{2}$ contained high polymeric $\mathrm{Al}$ species similar to those in $\mathrm{ACH}-2.5$, leading to low-temperature crystallization of $\alpha-\mathrm{Al}_{2} \mathrm{O}_{3}$. 
Mackenzie et al. ${ }^{37}$ assumed that low temperature $\alpha-\mathrm{Al}_{2} \mathrm{O}_{3}$ formation was associated with a 5-coordinated Al signal in the precursor. However, 5-coordinated $\mathrm{Al}$ does not seem to be the sole factor promoting the transformation to $\alpha-\mathrm{Al}_{2} \mathrm{O}_{3}$. For example, crystallite size of the starting precursor plays a significant role in the transformation of $\gamma-\mathrm{Al}_{2} \mathrm{O}_{3}$ to $\alpha-\mathrm{Al}_{2} \mathrm{O}_{3}{ }^{38}$. In our case, the $\mathrm{ACH}$ xerogels as precursors for $\alpha-\mathrm{Al}_{2} \mathrm{O}_{3}$ possessing a signal of $\mathrm{AlO}_{5}(\mathrm{ACH}-1.2$ and $\mathrm{ACH}-2.0)$ do not lead to the lowest temperature of $\alpha-\mathrm{Al}_{2} \mathrm{O}_{3}$ synthesis. In fact, non-heattreated ACH-2.5 xerogel, which does not show an $\mathrm{AlO}_{5}$ NMR signal, leads to lowtemperature $\alpha-\mathrm{Al}_{2} \mathrm{O}_{3}$ synthesis. We assume, that highly polymeric species in $\mathrm{ACH}-2.5$ lower the activation energy barrier to $\alpha-\mathrm{Al}_{2} \mathrm{O}_{3}$ crystallization due to the structural units similar to those of $\alpha-\mathrm{Al}_{2} \mathrm{O}_{3}$. These units serve as nucleation sites for the rest of $\mathrm{Al}$ atoms, which rearrange via 4- and 5-coordinated states of amorphous $\mathrm{Al}_{2} \mathrm{O}_{3}$ to form solely 6-coordinated state of $\alpha-\mathrm{Al}_{2} \mathrm{O}_{3}$. The occurrence of 4- and 5-fold coordinated $\mathrm{Al}$ species after heat-treatment of the xerogels, usually observed in amorphous $\mathrm{Al}_{2} \mathrm{O}_{3}$, could be explained by dehydroxylation. On the other hand, 5-coordinated $\mathrm{Al}$ in the structures of $\mathrm{ACH}-1.2$ and $\mathrm{ACH}-$ 2.0 xerogels represent structural units less similar to those in $\alpha-\mathrm{Al}_{2} \mathrm{O}_{3}$, which may hinder the nucleation of $\alpha-\mathrm{Al}_{2} \mathrm{O}_{3}$ and hence, do not contribute to the lowering of the $\alpha-\mathrm{Al}_{2} \mathrm{O}_{3}$ synthesis temperature. The crystallization of $\alpha-\mathrm{Al}_{2} \mathrm{O}_{3}$ from those samples proceeds via conventional route forming at first transition $\mathrm{Al}_{2} \mathrm{O}_{3}$ phases and then $\alpha-\mathrm{Al}_{2} \mathrm{O}_{3}$ by nucleation at 5 -coordinated $\mathrm{Al}$, preferentially localized on the surface of transition $\mathrm{Al}_{2} \mathrm{O}_{3}$. This process is reconstructive, requiring higher activation energy ${ }^{1,38}$. The latter crystallization path is followed also by the rest of the $\mathrm{ACH}-2.5$ sample that had not transferred to $\alpha-\mathrm{Al}_{2} \mathrm{O}_{3}$ at low temperature.

This article is protected by copyright. All rights reserved. 


\section{Conclusion}

In this work, structural changes from gelatinous aluminum chloride hydroxide, $\mathrm{ACH}$, to $\alpha-\mathrm{Al}_{2} \mathrm{O}_{3}$ powder was examined by liquid and solid-state ${ }^{27} \mathrm{Al}$ NMR as a main analytical tool. The hydrolysis ratio, $h$, defined as $\left[\mathrm{OH}^{-}\right] /\left[\mathrm{Al}^{3+}\right]$ was chosen as a varying parameter. The lowest temperature of $\alpha-\mathrm{Al}_{2} \mathrm{O}_{3}$ synthesis, $500{ }^{\circ} \mathrm{C}$, was attained by starting from $\mathrm{ACH}-2.5$, i.e. the solution with $h=2.5$. By comparing liquid and solid-state NMR spectra, the process of networking during the transition from $\mathrm{ACH}$ solution to anhydrous oxide, passing through ACH xerogel, was examined. Highly polymeric species, mainly ascribed to $\delta$ $\left[\mathrm{Al}_{2} \mathrm{O}_{8} \mathrm{Al}_{28}(\mathrm{OH})_{56}\left(\mathrm{H}_{2} \mathrm{O}\right)_{24}\right]^{18+}$, were revealed already in the solution phase with $h=2.5$ and became much more predominant in xerogel after drying. We conclude that the synthesis of $\alpha$ $\mathrm{Al}_{2} \mathrm{O}_{3}$ at $500{ }^{\circ} \mathrm{C}$ was feasible due to the preformation of the construction units in the precursor, which result in reducing of the energy barrier for its nucleation. Direct kinetic analyses for the explicit evaluation of the activation energy are yet to be done.

\section{Declaration of Interest}

Declarations of interest: none.

\section{Acknowledgements}

The authors thank Mr. S. Stahl (Institute of Nanotechnology, Karlsruhe Institute of Technology) for assistance with NMR measurements.

Funding: This work was supported by the Scientific Grant Agency VEGA of The Ministry of Education, Science, Research and Sport of the Slovak Republic [grant numbers 2/0092/14, 1/0712/18]; and the Deutsche Forschungsgemeinschaft [grant number SE 1407/4-

1]. P. H. is grateful to the State of Lower Saxony (Germany) for a Niedersachsen Professorship, from which also D. N. was supported. 


\section{References}

Wefers K, Misra C. Oxides and Hydroxides of Aluminum. Alcoa Tech Pap.1987; 19; $1-92$.

Brand $\mathrm{P}$, Troschke $\mathrm{R}$, Weigelt $\mathrm{H}$. Formation of $\alpha-\mathrm{Al}_{2} \mathrm{O}_{3}$ by thermal Decomposition of Basic Aluminium Chlorides at Low Temperatures. Cryst Res Technol. 1989;24(7):671-5.

Mishra P. Low-temperature synthesis of $\alpha$-alumina from aluminum salt and urea. Mater Lett. 2002;55(6):425-9.

S. Banerjee, P.S. Devi, Effect of citrate to nitrate ratio on the sol-gel synthesis of nanosized $\alpha-\mathrm{Al}_{2} \mathrm{O}_{3}$ powder, J. Therm. Anal. Calorim. 90 (2007) 699-706. Banerjee S, Devi PS. Effect of citrate to nitrate ratio on the sol-gel synthesis of nanosized $\alpha-\mathrm{Al}_{2} \mathrm{O}_{3}$ powder. J Therm Anal Calorim. 2007;90(3):699-706.

Heimann RB, Classic and Advanced Ceramics: From Fundamentals to Applications. Wiley-VCH Verlag GmbH \& Co. KGaA; 2010. 592

Ingram-Jones VJ, Slade RCT, Davies TW, Southern JC, Salvador S. Dehydroxylation sequences of gibbsite and boehmite: study of differences between soak and flash calcination and of particle-size effects. J Mater Chem. 1996;6(1):73-79.

Dynys FW, Halloran JW. Alpha Alumina Formation in Alum-Derived Gamma Alumina. J Am Ceram Soc. 1982;65(9):442-448.

Tsuchida T. Preparation and reactivity of acicular $\alpha-\mathrm{Al}_{2} \mathrm{O}_{3}$ from synthetic diaspore, $\beta$ $\mathrm{A}_{12} \mathrm{O}_{3} \cdot \mathrm{H}_{2} \mathrm{O}$. Solid State Ionics. 1993;63-65:464-470.

Kamiya K, Yotani J, Senba R, Matsuoka J, Nasu H. Sol-Gel Preparation of Gels Forming $\alpha$-Alumina around $500{ }^{\circ} \mathrm{C}$. J Ceram Soc Jpn. 1996;104(7):685-7. 
Macêdo MIF, Bertran CA, Osawa CC. Kinetics of the $\gamma \rightarrow \alpha$-alumina phase transformation by quantitative X-ray diffraction. J Mater Sci. 2007;42(8):2830-2836.

Hida M, Yamaguchi T, Fujita T, Taruta S, Kitajima K. Low-temperature formation of $\alpha$-alumina from plyhydroxoaluminum-lactic acid composite gels. J Ceram Soc Jpn. 2005;113(1315):226-231.

Casey WH, Phillips BL, Furrer G. Aqueous aluminum polynuclear complexes and nanoclusters: A review Rev Mineral. Geochem 2001;44(1):167-90.

Bi S, Wang C, Cao Q, Zhang C. Studies on the mechanism of hydrolysis and polymerization of aluminum salts in aqueous solution: Correlations between the "Core-links" model and "Cage-like" Keggin- $\mathrm{Al}_{13}$ model. Coord Chem Rev. 2004;248(5-6):441-55.

Perry CC, Shafran KL. The systematic study of aluminium speciation in medium concentrated aqueous solutions. J Inorg Biochem. 2001;87(1-2):115-124.

Seichter W, Mögel H, Brand P, Salah D. Crystal Structure and Formation of the Aluminium Hydroxide Chloride $\left.\left[\mathrm{Al}_{13}(\mathrm{OH})_{24} \mathrm{H}_{2} \mathrm{O}\right)_{24}\right] \mathrm{Cl}_{15} \cdot 13 \mathrm{H}_{2} \mathrm{O}$. Eur J Inorg Chem. 1998;1998(6):795-797.

Johansson G, Lundgren G, Sillén LG, Söderquist R. On the Crystal Structure of a Basic Aluminium Sulfate and the Corresponding Selenate. Acta Chem Scand. $1960 ; 14(3)): 769-771$.

Allouche, Gérardin, Loiseau, Férey, Taulelle. Al(30): A Giant Aluminum Polycation. Angew Chem Int Edit. 2000;39(3):511-514.

Fu G, Nazar LF, Bain AD. Aging processes of alumina sol-gels: Characterization of 
new aluminum polyoxycations by aluminum-27 NMR spectroscopy. Chem Mater. 1991;3(4):602-610.

Guo T, Chen R, Zhang X, Wu J, Wang H, Sun Z. Stability, morphological transformation and flocculability investigation of planar tridecameric $\mathrm{Al}_{13}(\mathrm{OH})_{24}\left(\mathrm{H}_{2} \mathrm{O}\right)_{24}{ }^{15+}$. Sep Purif Technol. 2017;184:288-297.

Akitt JW, Elders JM. Multinuclear magnetic resonance studies of the hydrolysis of aluminium(III). Part 8. Base hydrolysis monitored at very high magnetic field. J Chem Soc Dalt Trans. 1988;1:1347-1355.

Rowsell J, Nazar LF. Speciation and Thermal Transformation in Alumina Sols: Structures of the Polyhydroxyoxoaluminum Cluster $\left[\mathrm{Al}_{30} \mathrm{O}_{8}(\mathrm{OH})_{56}\left(\mathrm{H}_{2} \mathrm{O}\right)_{26}\right]^{18+}$ and Its

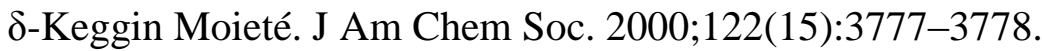

Shafran KL, Perry CC. A systematic investigation of aluminium ion speciation at high temperature. Part. 1. Solution studies. Dalt Trans. 2005;12:2098-2105.

Vogels R, Kloprogge JT, Geus JW. Homogeneous forced hydrolysis of aluminum through the thermal decomposition of urea. J Colloid Interface Sci. 2005;285(1):8693. ${ }^{24}$ Neuville DR, Cormier L, Massiot D. Al environment in tectosilicate and peraluminous glasses: A ${ }^{27} \mathrm{Al}$ MQ-MAS NMR, Raman, and XANES investigation. Geochim Cosmochim Acta. 2004;68(24):5071-5079.

d'Espinose de Lacaillerie JB, Fretigny C, Massiot D. MAS NMR spectra of quadrupolar nuclei in disordered solids: The Czjzek model. J Magn Reson. 2008;192(2):244-251. Haouas M, Taulelle F, Martineau C. Recent advances in application of ${ }^{27} \mathrm{Al}$ NMR spectroscopy to materials science. Prog Nucl Magn Reson Spectrosc. 2016;94-95:1136.

This article is protected by copyright. All rights reserved. 
Allouche L, Taulelle F. Conversion of A113 Keggin e into A130 : a reaction controlled by aluminum monomers. Inorg Chem Commun. 2003;6(9):1167-1170.

Abeysinghe S, Unruh DK, Forbes TZ. Crystallization of Keggin-type polyaluminum species by supramolecular interactions with disulfonate anions. Cryst Growth Des. 2012;12(4):2044-2051.

Smart SE, Vaughn J, Pappas I, Pan L. Controlled step-wise isomerization of the Keggin-type $\mathrm{Al}_{13}$ and determination of the $\gamma-\mathrm{Al}_{13}$ structure. Chem Commun. 2013;49(97):11352-11354.

Phillips BL, Ohlin CA, Vaughn J, Woerner WS, Smart S, Subramanyam R, Pan L. Solid-State ${ }^{27} \mathrm{Al}$ NMR Spectroscopy of the $\gamma-\mathrm{Al}_{13}$ Keggin Containing Al Coordinated by a Terminal Hydroxyl Ligand. Inorg chem. 2016;55(23):12270-12280.

Phillips BL, Vaughn JS, Smart S, Pan L. Characterization of $\mathrm{Al}_{30}$ in commercial polyaluminum chlorohydrate by solid-state ${ }^{27}$ Al NMR spectroscopy. J Colloid Interface Sci. 2016;476:230-239.

Bi Z, Feng C, Wang D, Ge X, Tang H. Transformation of planar Mögel $\mathrm{Al}_{13}$ to epsilon Keggin $\mathrm{Al}_{13}$ in dissolution process. Colloids Surf A. 2012;407:91-98.

Rustad JR, Loring JS, Casey WH. Oxygen-exchange pathways in aluminum polyoxocations1. Geochim et Cosmochim Acta. 2004;68(14):3011-3017.

Chen Z, Luan Z, Fan J, Zhang Z, Peng X, Fan B. Effect of thermal treatment on the formation and transformation of Keggin $\mathrm{Al}_{13}$ and $\mathrm{Al}_{30}$ species in hydrolytic polymeric aluminum solutions. Colloids Surf A. 2007;292(2-3):110-118.

Lee SK, Park SY, Yi YS, Moon J. Structure and disorder in amorphous alumina thin films: Insights from high-resolution solid-state NMR. J Phys Chem C. 2010;114(32):13890-13894.

This article is protected by copyright. All rights reserved. 
Brand P, Muller D, Gessner W. IR- and ${ }^{27}$ Al-NMR-spectroscopic Studies on Thermal Decomposition Products of Basic Aluminium Chlorides. Cryst Res Technol. 1990;25(8):951-956.

Mackenzie KJD, Temuujin J, Okada K. Thermal decomposition of mechanically activated gibbsite. Thermochim Acta. 1999;327(1-2):103-108.

Düvel A, Romanova E, Sharifi M, Freude D, Wark M, Heitjans P, et al. Mechanically Induced Phase Transformation of $\gamma-\mathrm{Al}_{2} \mathrm{O}_{3}$ into $\alpha-\mathrm{Al}_{2} \mathrm{O}_{3}$. Access to Structurally Disordered $\gamma-\mathrm{Al}_{2} \mathrm{O}_{3}$ with a Controllable Amount of Pentacoordinated Al Sites. J Phys Chem C. 2011;115(46):22770-22780.

\section{List of Table and Figure Captions}

Fig. 1. Scheme of synthesis procedure and characterizations of the samples.

Fig. 2. ${ }^{27} \mathrm{Al}$ NMR spectra of as-synthesized ACH solutions with different magnification $\left(v_{0}=\right.$ 78.2 MHz); a) ACH-0.0, b) ACH-0.5, c) ACH-1.2, d) ACH-2.0, e) ACH-2.5.

Fig. 3. Solid-state ${ }^{27} \mathrm{Al}$ MAS-NMR spectra of as-synthesized ACH xerogels with different magnifications $\left(v_{0}=156.4 \mathrm{MHz}, v_{\text {rot }}=40 \mathrm{kHz}\right)$; a) ACH- 0.0 , b) ACH-0.5, c) ACH1.2, d) ACH-2.0, e) ACH-2.5.

Fig. 4. Thermal analyses (DTA above, TG below) of the ACH xerogels; a) ACH-0.0, b) ACH-0.5, c) ACH-1.2, d) ACH-2.0, e) ACH-2.5.

Fig. 5. XRD patterns of heat-treated $\mathrm{ACH}$ xerogels at $500{ }^{\circ} \mathrm{C}, 600{ }^{\circ} \mathrm{C}, 800{ }^{\circ} \mathrm{C}, 1000{ }^{\circ} \mathrm{C}, 1200$ ${ }^{\circ} \mathrm{C}$; a) $\mathrm{ACH}-0.0$, b) $\mathrm{ACH}-0.5$, c) $\mathrm{ACH}-1.2$, d) $\mathrm{ACH}-2.0$, e) $\mathrm{ACH}-2.5 . *=\alpha-\mathrm{Al}_{2} \mathrm{O}_{3}$, broad unassigned diffractions belong to transition $\mathrm{Al}_{2} \mathrm{O}_{3}$.

Fig. 6. ${ }^{27} \mathrm{Al}$ MAS-NMR spectra of as-synthesized (below) and heat-treated ACH xerogels at $200{ }^{\circ} \mathrm{C}, 400{ }^{\circ} \mathrm{C}, 500{ }^{\circ} \mathrm{C}, 600{ }^{\circ} \mathrm{C}, 800{ }^{\circ} \mathrm{C}, 1000^{\circ} \mathrm{C}, 1200{ }^{\circ} \mathrm{C}\left(v_{0}=78.2 \mathrm{MHz}, v_{\text {rot }}=40\right.$ $\mathrm{kHz}$ ); a) ACH-0.0, b) ACH-0.5, c) ACH-1.2, d) ACH-2.0, e) ACH-2.5.

Tab. 1. Summarized results for aluminum chloride hydroxide samples from NMR and XRD.

This article is protected by copyright. All rights reserved. 


\section{Tables}

Tab. 1. Summarized results for aluminum chloride hydroxide samples from NMR and XRD

\begin{tabular}{|c|c|c|c|c|c|c|}
\hline \multirow[t]{2}{*}{ Label } & \multirow[t]{2}{*}{$h$} & \multirow{2}{*}{$\begin{array}{l}\text { Al species from solution }{ }^{27} \mathrm{Al} \mathrm{NMR} \\
\text { of ACH solutions with respective } \\
\text { NMR signals in ppm* }\end{array}$} & \multicolumn{3}{|c|}{$\begin{array}{l}\text { Signals of ACH xerogels from } \\
{ }^{27} \mathrm{Al} \text { MAS-NMR (ppm*) }\end{array}$} & \multirow{2}{*}{$\begin{array}{c}T \text { of } \alpha-\mathrm{Al}_{2} \mathrm{O}_{3} \\
\text { formation } \\
\text { from XRD }\end{array}$} \\
\hline & & & $\mathrm{AlO}_{4}$ & $\mathrm{AlO}_{5}$ & $\mathrm{AlO}_{6}$ & \\
\hline$\overline{\mathrm{ACH}-0.0}$ & 0.0 & "monomers (0) & - & - & -1 & $800^{\circ} \mathrm{C}$ \\
\hline ACH- 0.5 & 0.5 & monomers $(0)$; dimers, trimers $(4)$ & - & - & -1 & $600^{\circ} \mathrm{C}$ \\
\hline ACH-1.2 & 1.2 & $\begin{array}{l}\text { monomers }(0) \text {; dimers, trimers }(4) \text {; } \\
\varepsilon-\mathrm{K}_{-} \mathrm{Al}_{13}(63)\end{array}$ & 64 & 36 & 5 & $600{ }^{\circ} \mathrm{C}$ \\
\hline $\mathrm{ACH}-2.0$ & 2.0 & $\begin{array}{l}\text { monomers (0); dimers, trimers (4); } \\
\boldsymbol{\varepsilon}-\mathbf{K}-\mathbf{A l}_{\mathbf{1 3}}(\mathbf{6 3}) ; \delta \mathrm{Al}_{30}(13)\end{array}$ & 75 & 35 & $-2 ; 0 ; \mathbf{4} ; \mathbf{1 0}$ & $600^{\circ} \mathrm{C}$ \\
\hline ACH-2.5 & 2.5 & $\begin{array}{l}\text { monomers }(0) ; \\
\varepsilon-\mathrm{K}_{-}-\mathrm{Al}_{13}(63) ; \boldsymbol{\delta} \mathbf{A l}_{\mathbf{3 0}}(\mathbf{1 1} ; \mathbf{7 1})\end{array}$ & $67 ; 75$ & - & $-28 ; 0 ; \mathbf{5} ; \mathbf{1 0}$ & $500{ }^{\circ} \mathrm{C}$ \\
\hline
\end{tabular}

* The signals and the species with higher-intensity signals in ${ }^{27} \mathrm{Al}$ NMR and ${ }^{27} \mathrm{Al}$ MAS-NMR are in bold font

This article is protected by copyright. All rights reserved. 


\section{PREPARATION}

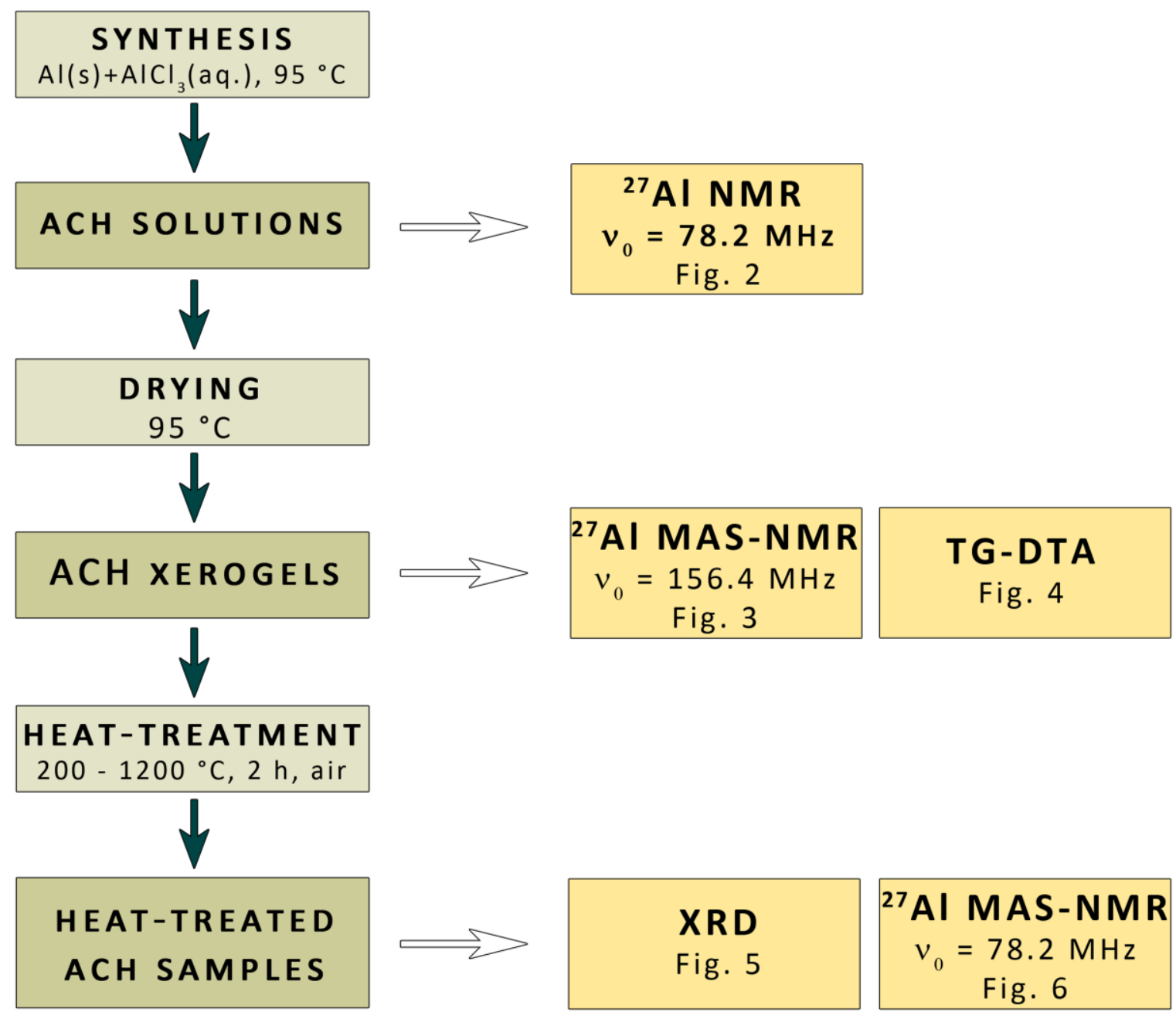


a)

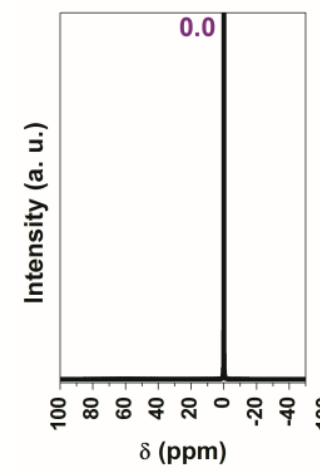

b)

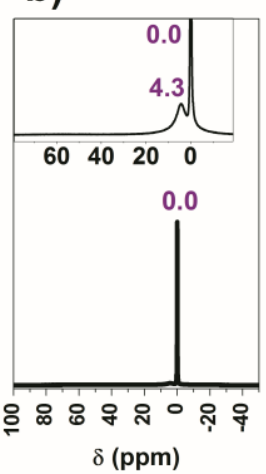

c)

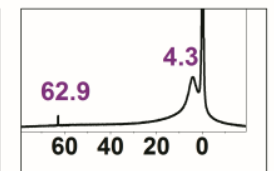

d)

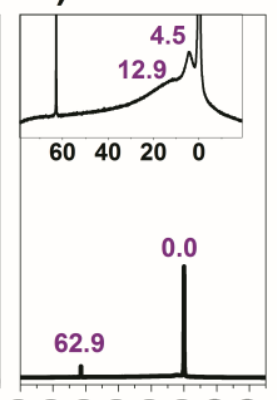

e)

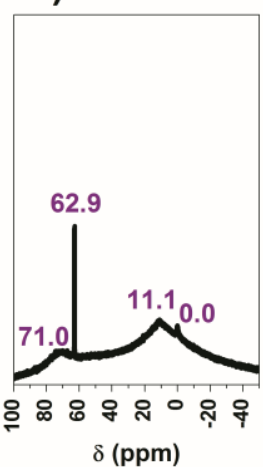

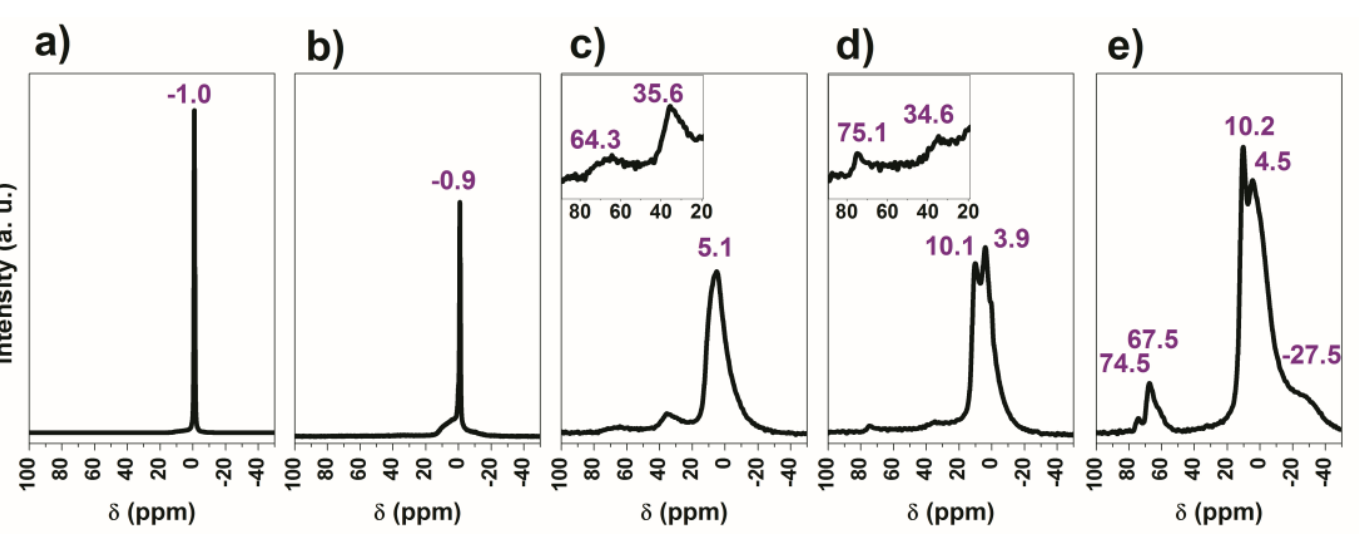

This article is protected by copyright. All rights reserved. 
a)

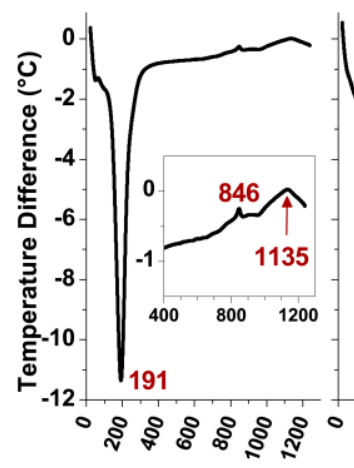

b)

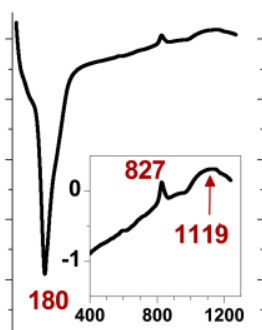

c)

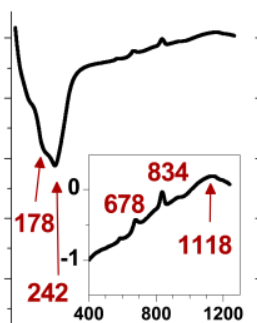

d)

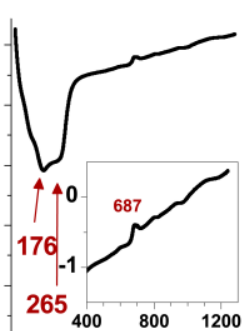

e)

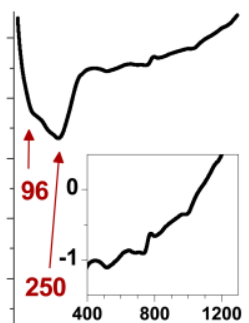

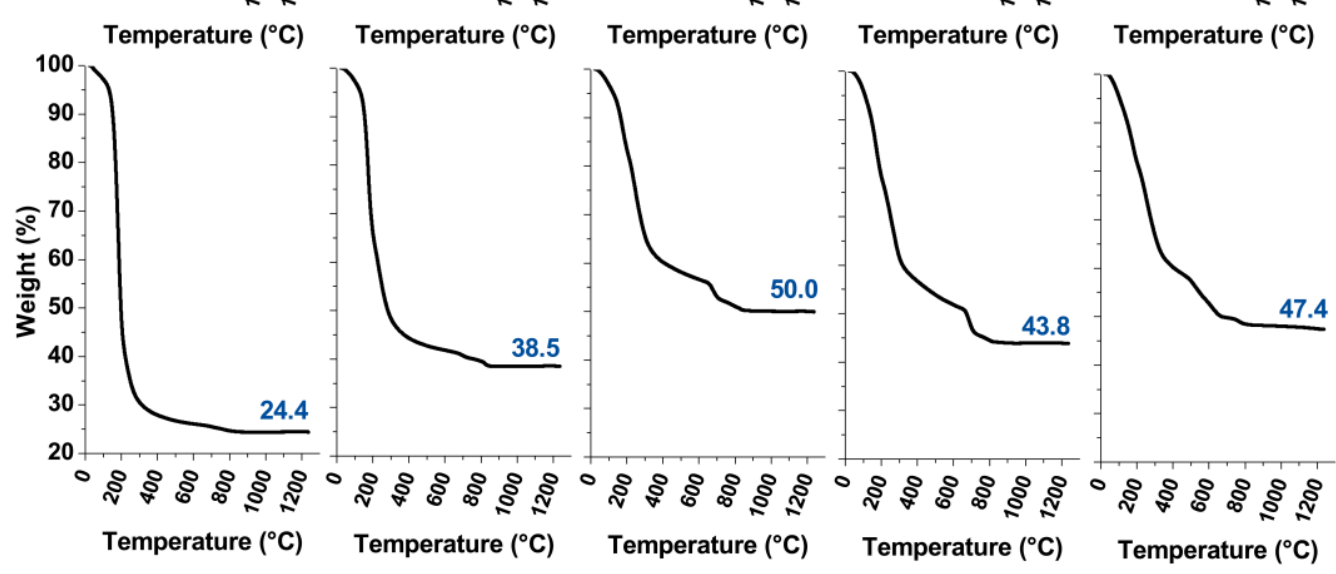

This article is protected by copyright. All rights reserved. 

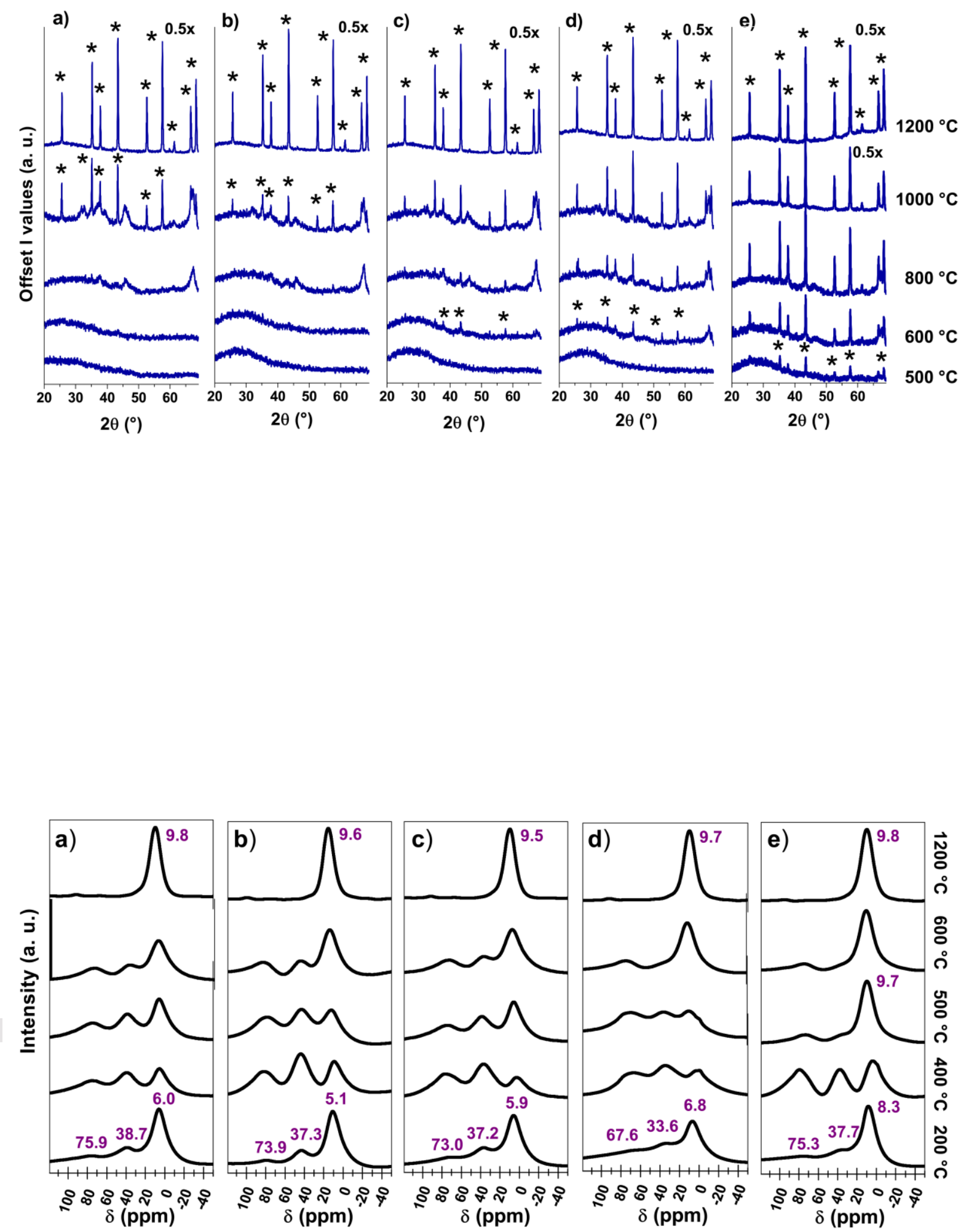

This article is protected by copyright. All rights reserved. 